[Agr. Biol. Chem., Vol. 34, No. 1, p. 146 148, 1970]

\title{
The Presence of Apopyruvate Carboxylase and Synthesis of Holopyruvate Carboxylase in Biotin Requiring \\ Baker's Yeast
}

Yeast pyruvate carboxylase (EC 6.4.1.1) which catalyzed the direct carboxylation of pyruvate to oxaloacetate in the presence of adenosine triphosphate ${ }^{11}$ was purified and shown to be a biotin-containing enzyme. ${ }^{21}$ It differs from those in liver, Pseudomonad ${ }^{3)}$ and Aspergilli" in its activation by both acetyl $\mathrm{CoA}$ and $\mathrm{CoA} .^{21}$ During the course of our studies in examining activity of biotin requiring baker's yeast, it was found that the activity of pyruvate carboxylase which was low in biotin deficiency was restored to about the same level of that found in biotin sufficient cells by incubating cell free extract with biotin, ATP and magnesium ion indicating the presence of apopyruvate carboxylase and holopyruvate carboxylase forming enzyme in biotin deficient yeast cells.

The baker's yeast, Saccharomyces cerevisiae strain BA-1 described in the previous paper ${ }^{51}$ was inoculated into the following synthetic medium: $10 \mathrm{~g}$ glucose, $1.05 \mathrm{~g}\left(\mathrm{NH}_{4}\right)_{2} \mathrm{SO}_{4}, 2.2 \mathrm{~g}$ $\mathrm{Na}_{2} \mathrm{HPO}_{4}, 2 \mathrm{~g}$ citric acid, $0.6 \mathrm{~g} \mathrm{KCl}, 0.5 \mathrm{~g}$ $\mathrm{MgSO}_{4} \cdot 7 \mathrm{H}_{2} \mathrm{O}, 0.1 \mathrm{~g} \mathrm{CaCl}_{2} \cdot 6 \mathrm{H}_{2} \mathrm{O}, 500 \mu \mathrm{g} \mathrm{H}_{3} \mathrm{BO}_{3}$, $400 \mu \mathrm{g} \mathrm{ZnSO}_{4} \cdot 7 \mathrm{H}_{2} \mathrm{O}, 200 \mu \mathrm{g} \mathrm{FeCl} \mathrm{F}_{3} \cdot 6 \mathrm{H}_{2} \mathrm{O}, 200$ $\mu \mathrm{g} \mathrm{MnSO}_{4} \cdot \mathrm{H}_{2} \mathrm{O}, 200 \mu \mathrm{g} \quad \mathrm{Na}_{2} \mathrm{MoO}_{4} \cdot 2 \mathrm{H}_{2} \mathrm{O}, 100$ $\mu \mathrm{g} \mathrm{KI}, 40 \mu \mathrm{g} \mathrm{CuSO}_{4} \cdot 5 \mathrm{H}_{2} \mathrm{O}, 2 \mathrm{mg}$ inositol, $400 \mu \mathrm{g}$

1) M. Losada, J. L. Canovas and M. Ruiz-Amil, Biochem. Z., 340, 60 (1964).

2) M. Ruiz-Amil, F. De. Torrontegui, E. Palacian, L. Cantana and M. Losada, J. Biol. Chem., 240, 3485 (1965)

3) W. Seubert and U. Remberger, Biochem. Z., 334, 401 (1961).

4) S.J. Bloom and M. J. Johnson, J. Biol. Chem., 237, 2718 (1962).

5) H. Kuraishi, Sci. Rep. Tohoku Univ. Ser. IV (Biol.), 25, 247 (1959). pyridoxine $\cdot \mathrm{HCl}, 400 \mu \mathrm{g}$ thiamine $\cdot \mathrm{HCl}, 400 \mu \mathrm{g}$

Ca-pantothenate. Either $0.08 \mu \mathrm{g} / \mathrm{liter}$ or 2 $\mu \mathrm{g} /$ liter of $\mathrm{D}$-biotin was added in biotin deficient or sufficient conditions, respectively. After incubated at $30^{\circ} \mathrm{C}$, yeast cells were harvested at the late log phase of growth by low centrifugation, washed twice with cold deionized water and once with $0.05 \mathrm{~m}$ Tris- $\mathrm{HCl}$ buffer of $\mathrm{pH} 7.6$ containing $5 \mathrm{~mm}$ glutathione, and suspended in the same buffer.

The yeast cells were disrupted with Braun cell homogenizer cooling with spraying carbon dioxide, and after removing cell debris by centrifugation at $15,000 \times g$ for $30 \mathrm{~min}$, supernatant was further ultracentrifuged at 105,000 $\times g$ for $60 \mathrm{~min}$. Resulting supernatant by ultracentrifugation was dialized against $1 / 50 \mathrm{M}$ potassium phosphate buffer of $\mathrm{pH} 6.8$ containing $5 \mathrm{~mm}$ cysteine for $3 \mathrm{hr}$. This fraction was referred to "cell free extract" and used for the experiments.

Assay of pyruvate carboxylase was carried out by the method of Ruiz-Amil et al. ${ }^{21}$ The synthesis of pyruvate carboxylase in the cell free extract was determined by its incubation in the following reaction mixture: $120 \mu$ moles of Tris-HCl ( $\mathrm{pH} 7.6), 12 \mu$ moles of ATP, 12 $\mu$ moles of $\mathrm{MgCl}_{2}, 1.2 \mu \mathrm{g}$ of $\mathrm{D}$-biotin and cell free extract $(1.0 \sim 3.0 \mathrm{mg}$ protein) in a total volume of $1.2 \mathrm{ml}$. After incubated at $25^{\circ} \mathrm{C}$, the activity of the holoenzyme formed in the aliquots of $0.1 \mathrm{ml}$ was determined by the same method as used in the assay of pyruvate carboxylase.

As shown in Table I, pyruvate carboxylase activity of the cells grown in biotin deficiency 
Table I. Pyruvate Carboxylase activities in BIOTIN DEFICIENT AND SUFFICIENT YEAST Cell EXTRACTS AND THE SyNTHESIS oF Holopyruvate CarboXYlase

Preincubation mixture contained in $1.2 \mathrm{ml}$. Tris (pH 7.6) $120 \mu$ moles, ATP $12 \mu$ moles, $\mathrm{MgCl}_{2} \cdot 6$ aq $12 \mu$ moles, biotin $1.2 \gamma$, enzyme protein $1.0 \sim 3.0 \mathrm{mg}$.

Pyruvate carboxylase assay mixture contained in a final volume of $1 \mathrm{ml}$ the following: $100 \mu$ moles of Tris-HCl ( $\mathrm{pH} 7.6$ ), $10 \mu$ moles of $\mathrm{MgCl}_{2} .6$ aq, 10 $\mu$ moles of Na-pyruvate, $10 \mu$ moles of $\mathrm{KH}^{14} \mathrm{CO}_{3}\left(10^{7}\right.$ cpm), $10 \mu$ moles of ATP, $1 \mu$ moles of NADH, 0.05 $\mu$ moles of CoASAc, $2.5 \mu$ moles of cysteine, 0.3 units of malate dehydrogenase. Aliquots of $0.2 \mathrm{ml}$ preincubation mixture were put into pyruvate carboxylase assay mixture.

After incubated for $4 \mathrm{~min}$ at $25^{\circ} \mathrm{C}$, the reaction was stopped by adding $0.2 \mathrm{ml}$ of $20 \%$ trifluoroacetic acid. The rate of ${ }^{14} \mathrm{CO}_{2}$ fixation was estimated for enzyme activities.

\begin{tabular}{|c|c|c|}
\hline \multirow{2}{*}{$\begin{array}{l}\text { Treatment of cell } \\
\text { free extract }\end{array}$} & \multirow{2}{*}{$\begin{array}{c}\text { Incuba- } \\
\text { tion } \\
\text { time } \\
\text { (min) }\end{array}$} & $\begin{array}{c}\text { Pyruvate-carboxylase } \\
\text { activity } a)\end{array}$ \\
\hline & & $\begin{array}{cc}\text { Biotin } & \text { Biotin } \\
\text { deficient cell } & \text { sufficient cell }\end{array}$ \\
\hline
\end{tabular}

\begin{tabular}{cccc}
\hline Preincubation with & & & \\
$\mathrm{ATP}+\mathrm{Mg}^{2+}$ & 0 & 100 & 780 \\
" & 6 & 107 & 733 \\
$\mathrm{ATP}+\mathrm{Mg}^{2+}+$ biotin & 0 & 143 & 830 \\
" & 6 & 860 & 962 \\
\hline
\end{tabular}

a) $0.28 \mathrm{~m} \mu \mathrm{mole} / \mathrm{mg}$ protein $/ \mathrm{min}$ of $\mathrm{CO}_{2}$ fixed was expressed as 100 .

was about $1 / 7.8$ of that grown at biotin sufficient condition and about $1 / 6.85$ even after incubated for $6 \mathrm{~min}$ in the presence of ATP and $\mathrm{Mg}^{2+}$ without biotin. However, the incubation of cell free extract from biotin deficient cells with ATP, $\mathrm{Mg}^{2+}$ and biotin for $6 \mathrm{~min}$ restored pyruvate carboxylase activity to about 8.6 fold, although slight increase of activity (about 1.2 fold) was observed even in biotin sufficient cells. The level of pyruvate carboxylase activity in biotin deficient cells after incubation of cell free extract with ATP, $\mathrm{Mg}^{2+}$ and biotin was about the same as that of biotin sufficient cells. This result indicates that pyruvate carboxylase is present as apopyruvate carboxylase in biotin deficient yeast and the synthesis of holopyruvate carboxylase is dependent on holoenzyme synthetase or ligase as has been known in other biotin containing enzymes. ${ }^{6,71}$

As illustrated in Fig. 1, holopyruvate carboxylase synthesis depends on the preincubation time. The cofactor requirements of holopyruvate carboxylase forming enzyme were shown in Table II. The holoenzyme synthetase or ligase showed to require ATP for the completion of the reaction. Without magnesium ion, a marked reduction in pyruvate carboxylation was not observed, but further addition of EDTA to this magnesium free mixture resulted in the reduction of activity to 20\%. It is suggested that the enzyme preparation may contain magnesium

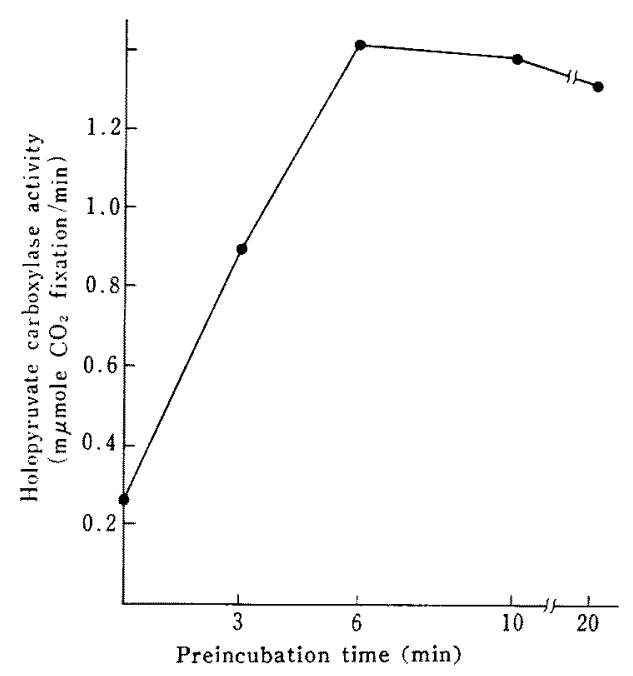

FIG. 1. Kinetics of Holopyruvate Carboxylase Synthesis.

Holopyruvate carboxylase synthesis was carried out by preincubating the biotin deficient enzyme with ATP, $\mathrm{Mg}^{2+}$ and (D)-biotin. The preincubation mixture and the method of determining the pyruvate carboxylase were shown in Table $I$. Protein used was $1.6 \mathrm{mg}$.

6) D. P. Kosow, S. C. Huang and M. D. Lane, $J$. Biol. Chem., 237, 3633 (1962).

7) K.L. Rominger, Ph. D. Thesis München, 1964. 
TABLE II. COFACTOR REQUIREMENTS FOR Holopyruvate CarboXylase SYNTHESIS

Complete preincubation mixture, and assay of pyruvate carboxylase were same as shown in Table $I$.

\begin{tabular}{lc}
\hline $\begin{array}{c}\text { Deletions from or additions to } \\
\text { complete reaction mixture }\end{array}$ & $\begin{array}{c}\text { Enzyme activity } \\
(\%)\end{array}$ \\
\hline None & 100 \\
Biotin omitted & 12 \\
ATP omitted & 53 \\
ATP and Mg ${ }^{2+}$ omitted & 43 \\
Mg omitted & 76 \\
Mg omitted, EDTA & al added \\
\hline
\end{tabular}

a) EDTA added was $0.5 \mu$ mole.

cation to support appreciable holopyruvate carboxylase synthesis, and magnesium ion is assumed to be required for the holoenzyme synthesis.

Although the existence of apoenzymes in biotin deficiency has been reported in other biotin enzymes, such as propionyl CoA carboxylase (EC6.4.1.3), ${ }^{6}$ methyl malonyl CoA pyruvate carboxytransferase (EC 2.1.3.1), ${ }^{81}$ acetyl CoA carboxylase (EC 6.4.1.2) ${ }^{\prime \prime}$ and $\beta$-methyl crotonyl CoA carboxylase (EC 6.4.1.4), ${ }^{9}$ it was now confirmed that pyruvate carboxylase was also present as apoenzyme in biotin deficiency and synthesis of holoenzyme from apoenzyme required biotin, ATP and magnesium ion.

The authors wish to express their thanks to Dr. Y. Ozawa for his advice through these experiments.

Takemitsu Mizunaga

Hiroshi KuRaISHI

Kô AIDA

Teijiro Uemura

Institute of Applied Microbiology,

University of Tokyo,

Bunkyo-ku, Tokyo,

Japan

Received October 9, 1969

8) M.D. Lane, D. L. Young and F. Lynen, $J$. Biol. Chem., 239, 2858 (1964).

9) H. Thomas and J. Knappe, Biochem. Z, 342, 190 (1965). 